\title{
REFORMA UNIVERSITÁRIA NO BRASIL - 1995-2006: PRECÁRIA TRAJETÓRIA E INCERTO FUTURO*
}

\author{
VALDEMAR SGUISSARDI**
}

\begin{abstract}
Art. $1^{\circ}$ - Esta Lei estabelece normas gerais da educação superior, regula a educação superior no sistema federal de ensino e altera a lei de diretrizes e bases da educação nacional. (Projeto de Lei de Reforma da Educação Superior)
\end{abstract}

\begin{abstract}
RESUMO. Este artigo visa percorrer os caminhos da reforma universitária no Brasil, no período de 1995-2006, que poderá ter como última etapa a aprovação ou não do Projeto de Lei da Reforma Universitária, elaborada pelo governo Lula da Silva, em tramitação no Congresso Nacional. Além de apresentar o contexto macroeconômico e político em que se tem processado a reforma da educação superior no país, em cuja orientação se destacam algumas teses disseminadas por organismos (financeiros) multilaterais, busca-se mostrar: 1) como houve muito mais continuidades que rupturas entre os governos FHC e o governo Lula da Silva, tanto no campo da economia e da administração pública, como da educação superior; 2) como a atual versão (Casa Civil) do Projeto de reforma universitária, apesar de precedida de amplo e inédito processo de discussão pública, nem faz jus ao Plano de Governo Lula para a educação superior (2003-2006), nem garante sequer alguns avanços em relação à autonomia e ao financiamento (das IFES) presentes na sua versão anterior (MEC). Conclui com a hipótese de que, dada a conjuntura política atual, dificilmente este projeto será aprovado no Congresso Nacional e, se o for, tenderá a apresentar mudanças que aprofundariam o caráter neopragmático e eficientista da reforma em curso nos últimos anos.
\end{abstract}

Palavras-chave: Reforma universitária. Educação superior. Universidade.

* Este artigo é uma versão atualizada de comunicação apresentada no Seminário do Projeto Monitoramento Ativo da Participação da Sociedade (MAPAS). Rio de Janeiro, IBASE, 12 de dezembro de 2005.

** Doutor em Ciências da Educação e professor titular da Universidade Metodista de Piracicaba (UNIMEP).E-mail: vs@merconet.com.br

Educ. Soc., Campinas, vol. 27, n. 96 - Especial, p. 1021-1056, out. 2006

Disponível em <http://www.cedes.unicamp.br> 
Reforma Universitária no Brasil - 1995-2006: Precária trajetória e incerto futuro

UNIVERSITY REFORM IN BRAZIL - 1995-2006:

PRECARIOUS TRAJECTORY AND UNCERTAIN FUTURE

ABSTRACT: This paper aims at following the trails of the university reform in Brazil., between 1995-2006, whose latest stage might be the passing or not, by the Brazilian Congress, of the University Reform Bill elaborated by the Lula administration. It presents the macroeconomic and political context surrounding the reform of higher university, whose orientation contains theses disseminated by multilateral (financing) organisms. It also seeks to show that: 1) there were much more continuities than discontinuities between the governments of Mr. Fernando Henrique Cardoso and Mr. Lula da Silva, both in the fields of economy and public administration, and of higher education. 2) That, although it was preceded by a long and unprecedented public discussion process, the current version (Casa Civil) of the University Reform Bill does not do justice to the Lula Government Plan for higher education (2003-2006) nor does it guarantee any advance in what regards the autonomy and financing of the Higher Education Institutes and Faculties present in the previous version (MEC). The text concludes with the hypothesis that, in the current political conjuncture, the Brazilian Congress will not approve this bill unless it suffers amendments that would deepen the neo-pragmatic and efficientist character of the reform that has been in progress these last years

Key words: University reform. Higher education. University.

\section{Introdução}

$\mathrm{O}$

projeto de lei de reforma da educação superior encaminhado pelo Poder Executivo ao Congresso Nacional, em 12 de junho de 2006 (PL 7.200), apesar de revogar três leis, entre elas a Lei n. 5.540/68 (Lei da Reforma Universitária), e de alterar outras cinco, entre as quais a Lei n. 9.394/96 (Lei de Diretrizes e Bases da Educação Nacional), se aprovado, ainda assim não conterá toda a reforma. Tratar-se-á, na verdade, da última etapa, importante, de um processo que se desdobra há pelo menos uma década, isto é, desde o início do governo Fernando Henrique Cardoso (FHC), em janeiro de 1995.

Esse projeto, em sua presente versão (quarta) da Casa Civil, com características diferentes da última versão do Ministério da Educação e do Desporto (terceira, de julho/2005) - como se verá mais adiante -, 
se aprovado na forma atual, poderá provocar mudanças na orientação da reforma da educação superior em curso nesta última década, embora mudanças muito aquém do que se poderia esperar do proposto pelo Plano do Governo Lula para o período 2002-2006. A primeira dessas foram os procedimentos adotados em suas diferentes etapas de formulação, em que, durante cerca de dois anos, esteve aberta a ampla discussão da sociedade civil organizada ou não. Isso, não independentemente do resultado final, poderá ser importante para o sucesso de sua eventual futura implantação. A segunda são as bandeiras desfraldadas ou os objetivos centrais que visaria alcançar:

(i) constituir um sólido marco regulatório para a educação superior no País; (ii) assegurar a autonomia universitária prevista no art. 207 da Constituição, tanto para o setor privado quanto para o setor público, preconizando um sistema de financiamento consistente e responsável para o parque universitário federal; e (iii) consolidar a responsabilidade social da educação superior, mediante princípios normativos e assistência estudantil. (Brasil, 2006b).

Entretanto, essas bandeiras ou esses objetivos centrais defrontam-se com dois grandes potenciais obstáculos, condicionantes de sua aprovação e efetividade: de um lado, a própria legislação anterior, incluída a aprovada durante o Governo Lula, entre elas as Leis da Parceria Público-Privada (PPP), da Inovação Tecnológica e do Programa Educação para Todos (PROUNI), mas principalmente a visão/concepção dominante no Ministério da Fazenda em relação ao lugar que deve ocupar a educação superior nas despesas do fundo público, concepção que continua muito próxima da disseminada por organismos multilaterais, como Banco Mundial (BM), o Banco Interamericano do Desenvolvimento (BID) e a Organização Mundial do Comércio (OMC), seguida bastante à risca no octênio FHC (Brasil, 2003); e, de outro, diante da atual crise política, a fragilidade das posiçōes do Poder Executivo no Congresso Nacional, onde facilmente tenderão a se aglutinar as forças representantes dos interesses do setor privado/mercantil, que poderão reduzir sensivelmente o alcance dessas bandeiras, ou modificá-las radicalmente, da mesma forma que já o fizeram em relação à proposta governamental do PROUNI em passado recente.

Para demonstrar essas hipóteses, será examinada, no item 1 deste texto, ainda que de forma sucinta, a questão universitária ou da educação superior no Brasil no período 1995-2002. Neste item, serão destacadas algumas características do sistema de educação superior do país, dentre 
elas: as restritas dimensōes do campo, a diferenciação institucional, a expansão do setor privado e a restrição gradativa do setor público, a desigual distribuição regional, a (má) distribuição por área de conhecimento, a concentração da pós-graduação no setor público e na região Sudeste (em especial em São Paulo), a questão da avaliação ("Provão"), o modelo universitário predominante (e em franca expansão), isto é, da universidade de ensino em detrimento da universidade de pesquisa. Destacar-se-á, também, o esforço de produção de um acervo legislativo ou de marcos regulatórios, que, em grande medida, traduziram (ou coincidiram com) orientações fundadas em teses disseminadas mundialmente por instituiçōes e organismos multilaterais (BM, BID, OMC e Consenso de Washington) e por órgãos e institutos universitários no país (Núcleo de Pesquisas sobre Ensino Superior da USP - NUPES, entre outros). Esses marcos, presentes na Lei n. 9.394/96 (LDB) e em outras leis, decretos e portarias, balizaram a expansão restrita do setor público e a desenfreada expansão do setor privado no nível de graduação. Isso se efetivou de várias formas, por medidas tais como as de restrição do financiamento e da autonomia do setor público federal, e de liberação, com mínimos controles, da criação de instituições de ensino superior (IES) privadas; principalmente isoladas ou no máximo constituídas como centros universitários (estes com autonomia para criarem cursos, mas sem a obrigação da produção de conhecimentos por meio de pesquisa). Neste item, terá lugar especial o Plano Nacional de Educação (PNE) para registro de sua importância política e de como, em razão de diversos vetos presidenciais, quando de sua sanção em janeiro de 2001, tornou-se uma simples "carta de intençōes", ao invés de um plano orientador de políticas de Estado.

No item 2, far-se-á breve apresentação das principais teses que têm orientado as "reformas pontuais" da educação superior no Brasil e que, fundadas em especial no diagnóstico neo ou ultraliberal da economia e do Estado, assim como nos documentos do BM, do BID e da OMC, estão conduzindo a universidade brasileira a transitar de adaptaçôes dos modelos clássicos de universidade (napoleônico ou humboldtiano) para "modelos de ocasiāo" fundados nessas teses. Estes podem ser denominados de "modelo da universidade mundial do Banco Mundial" ou de "modelo anglosaxão". Também se poderia falar do modelo que está sendo gerado na Comunidade Econômica Européia (CEE), a partir especialmente da Declaração de Bolonha (1999), que tenderá a influenciar as reformas no Brasil e na América Latina em futuro próximo. Cada um desses "modelos de ocasião" 
pode ser caracterizado pelos qualificativos neoprofissional, heterônomo e competitivo ou, ainda, como escreve Chauí (1999), funcional e operacional.

No item 3, apresentar-se-á em breves traços o cenário da educação superior durante os três anos e meio do Governo Lula. Caberá fazer rápida menção ao Plano de Governo para a Educação Superior (diagnóstico e propostas que retomam parcialmente o PNE) e à legislação produzida durante o atual governo (leis das PpPs, da Inovação Tecnológica, do PROUNI e do SINAES, entre outras), que condiciona o alcance deste novo projeto de lei de reforma universitária.

No item 4, proceder-se-á a uma análise dos traços e do significado do projeto de lei da reforma da educação superior enviado ao Congresso Nacional: o sistema de educação superior, a autonomia universitária, o financiamento das instituições federais de ensino superior (IFES), o novo sistema de avaliação, a associação ensino-pesquisa-extensão, a democratização da universidade (no âmbito da estrutura e organização do poder interno e em relação ao acesso e permanência dos grupos sociais hoje excluídos por razōes de pobreza ou raça) e os novos padrões de exigência quanto à carreira docente, aos vínculos institucionais, à qualificação docente e aos padrões para credenciamento e recredenciamento das IES, aspectos que garantiriam a qualidade e regulação do sistema federal público e privado.

Nas considerações finais serão reiteradas algumas das características do sistema universitário no Brasil, hoje composto por universidades neoprofissionais (ou essencialmente de ensino), heterônomas (dependentes cada vez mais de agenda externa), competitivas (no caso das públicas, que necessitam, a cada dia, buscar mais recursos da iniciativa privada para complemento das verbas do fundo público, além de implantarem gerenciamento empresarial e instituírem fundações privadas de apoio institucional). Por fim, serão feitas considerações sobre as dificuldades de o projeto de lei da reforma universitária, a tramitar no Congresso Nacional, ser aprovado no formato encaminhado pelo Poder Executivo e produzir os resultados dele esperados.

\section{A educação superior no Brasil de 1995 a 2002 e as "reformas pontuais"}

Os anos de 1995 a 2002, por corresponderem ao octênio presidencial de FHC, foram marcados pela continuidade administrativa tan- 
to na esfera da economia como na da educação (os dois ministros dessas áreas permaneceram no cargo por oito anos).

Não se pode falar sobre a questão da educação superior nesse período sem situá-la no contexto mais amplo da inserção subalterna do país à economia global e na permanência ou no agravamento dos inaceitáveis índices de desigualdade social na década de 1990 e nesse período de dois mandatos presidenciais.

O que se denomina de modernização conservadora, que se iniciou com o governo de Collor de Mello (1990-1991) e seguiu-se no de Itamar Franco (1992-1994), recrudesceu no de FHC (1995-2002). Nesse período, em especial no Governo FHC, efetivou-se uma série de ajustes estruturais e fiscais ou de reformas orientadas para o mercado. No octênio FHC, ocorreram as principais conducentes à reconfiguração das esferas pública e privada, no âmbito do Estado, assim como da educação superior. ${ }^{1}$

A integração do país à economia mundial dá-se enfatizando o novo papel atribuído ao mercado na alocação dos recursos e diminuindo as funçôes do Estado, em especial quando este é pensado como provedor dos serviços sociais, entre eles, a educação. As medidas recomendadas, como se sabe, foram: combate ao déficit público, ajuste fiscal, privatização, liberação/ajuste de preços, desregulamentação do setor financeiro, liberação do comércio, incentivo aos investimentos externos, reforma do sistema de previdência/seguridade social e reforma, desregulamentação e flexibilização das relaçôes de trabalho.

São suficientemente conhecidas as recomendações do Consenso de Washington, que sintetizariam, ao final da década de 1980, as recomendaçôes de organismos como o Fundo Monetário Internacional (FMI) e do BM, entre outros, para que se precise comentá-las. Bastará aqui relacionálas: equilíbrio orçamentário, sobretudo mediante a redução dos gastos públicos; abertura comercial, pela redução das tarifas de importação e eliminação das barreiras não-tarifárias; liberalização financeira, pela reformulação das normas que restringem o ingresso de capital estrangeiro; desregulamentação dos mercados domésticos, pela eliminação dos instrumentos de intervenção do Estado, como controle de preços, incentivos etc.; e privatização das empresas e dos serviços públicos.

No período em foco, buscou-se o equilíbrio orçamentário, como regra e a cada sobressalto oficial diante das incertezas da economia, me- 
diante cortes nos gastos com os serviços públicos e, em especial, com a aprovação da Lei da Responsabilidade Fiscal. Os demais cânones liberalizantes acima citados e, principalmente, a privatização das empresas estatais e dos serviços públicos foram todos, enfim, seguidos bastante à risca. De dezenas e dezenas de empresas estatais, por exemplo, restaram apenas algumas de grande expressão, como a PETROBRÁs, o Banco do Brasil e a Caixa Econômica Federal.

Em 1995, segundo o Departamento Intersindical de Estatística e Estudos Socioeconômicos (DIEESE), o Brasil apresentava o seguinte quadro de distribuição pessoal de renda do trabalho: o $1 \%$ mais rico obtinha $13,9 \%$ da renda total do trabalho, maior que os $13,0 \%$ da renda obtida pelos $50 \%$ mais pobres; os $5 \%$ mais ricos obtinham $36,6 \%$ da renda, cerca de oito vezes a renda obtida pelos $30 \%$ mais pobres da população, que obtinham apenas $4,4 \%$ da renda do trabalho; os $10 \%$ mais ricos obtinham $48,2 \%$ da renda total do trabalho, enquanto os $10 \%$ mais pobres obtinham apenas 1,1\% (DIEESE, 2001, p. 35).

Esse quadro de concentração de renda manteve-se praticamente inalterado durante o período em estudo, o que mostra que as políticas públicas na economia e nos serviços não tiveram caráter distributivo de renda. Nesse contexto, devem ser vistos o quadro da educação superior e as "reformas pontuais" por que esse tem passado.

Alguns dados e aspectos da educação superior no período 1994-2002

Em ordem e forma aleatórias, podem ser elencados alguns dados e aspectos importantes da educação superior no Brasil nesse período, principalmente relacionados ao nível da graduação:

\section{A cobertura do sistema}

Em relação à população da faixa etária de 18 a 24 anos, a taxa de cobertura líquida no período foi de aproximadamente 7\%. Trata-se de uma das mais baixas na América Latina, em que há casos de países, como a Argentina, o Chile e o Uruguai, que já ultrapassavam, em 2002, os 30\%, meta que o Brasil estabeleceu para o ano 2011, isto é, dez anos após a aprovação do Plano Nacional de Educação em janeiro de 2001. 


\section{A diversidade institucional}

Para um total de 851 IES em 1994, apenas 127 eram universidades, 87 eram faculdades integradas e 637 eram faculdades ou instituições isoladas. No ano de 2004, as IES já somavam 2.013, das quais 169 universidades, 107 centros universitários 1.737 faculdades, faculdades integradas, faculdades tecnológicas e centros de educação tecnológica.

\section{A privatização do sistema}

A distribuição entre o setor público e o setor privado tem evoluído no sentido de aprofundar a predominância deste em relação àquele, situando o Brasil, hoje, como o país de maior índice de privatização na América Latina e entre os cinco de maior índice de privatização no mundo, se considerados o número de IES e o percentual de matrículas. Em 1994, das 851 IEs, $192(22,5 \%)$ eram públicas e $659(77,5 \%)$ eram privadas. Em 2002, das 1.637 IES, 195 (11,9\%) eram públicas e $1.442(88,1 \%)$ eram privadas. Nesse período de oito anos, as IES privadas passaram de $77,5 \%$ para $88,1 \%$. O número de IES cresceu $92 \%$; o de IES públicas permaneceu estável; o das IES privadas cresceu $118 \%$. O mesmo fenômeno verifica-se em relação à evolução das matrículas. No período 1994-2002, para um aumento do total de matrículas da ordem de $109 \%$, o do setor privado foi de $150 \%$, três vezes maior que o do setor público, de apenas 52\%. Cabe registrar, ainda assim, que o principal aumento no setor público se deu nas estaduais. O setor privado, que, em 1994, concentrava 58\% das matrículas, em 2002 já concentrava $70 \% .^{2}$

\section{A distribuição regional}

Cabe destacar as distorçôes da distribuição regional da educação superior no país, no caso das IES e vagas oferecidas no período. No ano 2000, para um total de 1.216.287 vagas, o setor privado ofereceu 970.655 ou $79,8 \%$, e o setor público, 245.632 ou 20,2\%. Destaquem-se os casos das regióes Nordeste e Sudeste. Aquela, com 29\% da população brasileira, conta com apenas $13 \%$ das IES e 12\% das vagas; esta, com $43 \%$ da população, conta com $56 \%$ das instituições e $58 \%$ das vagas. 
Verifica-se também que o percentual de IES e de vagas públicas está bastante próximo do percentual regional da população, com algum percentual a mais de oferta no caso do Norte e do Centro-Oeste e, a menos, no caso do Sudeste. Em contrapartida, as IES e as vagas privadas concentram-se principalmente no Sudeste (60\% e 64\%, respectivamente, para uma população de $43 \%$ do total). No Nordeste, para uma população de $29 \%$ do país, localizam-se apenas $11 \%$ das IES e $7 \%$ das vagas privadas. $^{3}$

\section{Concentração por área de conhecimento}

Outro traço da educação superior do período, que tendeu a se agravar nos anos seguintes, é o da concentração por área de conhecimento. No ano 2000 a área de ciências sociais aplicadas (administração, direito, contabilidade, negócios) concentrava 41,6\% do total de matrículas. As IES privadas concentravam, nos cursos dessa área, 50,1\% de suas matrículas, contra $24 \%$ nas federais e $20 \%$ nas estaduais. A área de educação concentrava outros $21,7 \%$ do total de vagas, restando apenas cerca de $37 \%$ das vagas para todas as demais áreas do conhecimento. Essa concentração verifica-se em especial no setor privado, em razão, por hipótese, dos baixos investimentos exigidos e dos altos retornos financeiros. As áreas que requerem maiores investimentos, como as de engenharia, saúde, entre outras, tendem a ser majoritariamente atendidas pelo setor público.

\section{A concentração no ensino noturno (no setor privado)}

Cerca de $57 \%$ das matrículas de graduação no país concentravam-se, nesse período, no ensino superior noturno: em torno de $67 \%$ das matrículas da rede privada e $30 \%$ da rede pública.

\section{Concentração regional da pós-graduação}

De forma muito mais acentuada que na graduação, dá-se a concentração regional da pós-graduação. A grande diferença em relação à graduação é a inversão da concentração por dependência administrativa: na pós-graduação ela ocorre no setor público, em especial no doutorado, e aqui ocupam lugar relevante as estaduais e, entre estas, as

Educ. Soc., Campinas, vol. 27, n. 96 - Especial, p. 1021-1056, out. 2006 
paulistas Universidade de São Paulo (USP) e Universidade Estadual de Campinas (UNICAMP).

No ano de 1999, por exemplo, a pós-graduação stricto sensu estava extremamente concentrada no setor público, com $86,7 \%$, contra $13,3 \%$ no setor privado. No nível do mestrado, o setor público respondia por $84,6 \%$ e o setor privado, por $15,4 \%$. No nível do doutorado, o setor público respondia por $90,9 \%$ e o setor privado, por apenas $9,1 \%$.

A concentração regional verifica-se quando analisados os dados do Sudeste (e Sul) em confronto com os dados globais. O Sudeste concentrava $65 \%$ das matrículas do mestrado e $80,3 \%$ do doutorado. As estaduais - e, como já observado, especialmente as paulistas - concentram cerca de $50 \%$ de todas as matrículas de doutorado do país: 14.176, para um total de 29.940.

\section{Financiamento das IFES}

Para se analisar as políticas públicas de educação superior durante esse período, um indicador importante é o do financiamento federal das IFES, obrigação constitucional. O índice mais utilizado é do percentual em relação ao PIB, ano a ano, do total de recursos destinados ao conjunto das IFES.

Os recursos destinados às IFES no ano 1989 corresponderam a 0,97\% do PIB. Em 1994, eles correspondiam a 0,91\%. Oito anos passados, eles correspondiam a $0,64 \%$ e, no ano anterior, tinham correspondido a $0,61 \%$, numa redução de cerca de $33 \%$ em relação ao início do octênio governamental. Caso fosse tomado como referência o total das despesas correntes do fundo público federal, a queda no índice se revelaria ainda mais acentuada: $44 \%$.

Ocorre registrar que, no período 1994-2002, o ensino superior público federal teve uma expansão de $37 \%$ nas matrículas e uma redução de $5 \%$ no seu corpo docente e de $21 \%$ no seu quadro de funcionários, além do quase congelamento salarial de docentes e funcionários técnico-administrativos. Esse congelamento foi parcialmente compensado apenas por uma gratificação proporcional aos índices individuais de "produtividade", intitulada, no caso dos docentes, de gratificação de estímulo à docência (GED). 
O custo/aluno, um dos principais alvos da crítica ao ensino superior federal, excluídos os gastos com hospitais universitários e outros não relacionados diretamente ao ensino, sofreu, no período de 1995-2001, uma redução de $51 \%$ (de $R \$ 11.198,00$ para $R \$ 5.488,00$ ). Esse porcentual de redução, com valores a preços de janeiro de 2002 (IGP-DI/ FGV), como fração do PIB nacional, foi de 53,7\% (Amaral, 2003 p. 123). ${ }^{4}$

\section{Autonomia de gestão financeira $x$ autonomia financeira}

Entre as iniciativas oficiais para redução do financiamento federal da educação superior, no caso das IFES, durante o governo FHC, por iniciativa do MEC, foram feitas várias tentativas de aprovar, no Congresso Nacional, emendas constitucionais ou leis ordinárias que promovessem a autonomia, em lugar da autonomia de gestão financeira (constitucional), que autorizaria as IFES a arrecadarem fundos de qualquer natureza, na ausência do financiamento estatal (constitucional). Além disso, visando compensar a desobrigação do Estado com a plena manutenção das IFES, incentivou-se a criação das polêmicas Fundações de Apoio Institucional (FAI), entidades privadas no interior dos campi universitários. ${ }^{5}$

\section{Exame Nacional de Cursos ("Provão")}

Em lugar de um sistema de avaliação que visava conciliar as exigências oficiais de supervisão, regulação e controle e a auto-avaliação institucional pelas comunidades universitárias, estruturado sob a gestão do ministro Murílio Hingel (Governo Itamar Franco) e denominado Programa Avaliação Institucional das Universidades Brasileiras (PAIUB), a partir de 1997 passou-se a utilizar um sistema de avaliação da educação superior que comportava fundamentalmente dois instrumentos: exame das condiçōes de oferta (infra-estrutura, currículo acadêmico, qualificação docente etc.) e o Exame Nacional de Cursos ("Provão"), consistente numa única prova escrita, com predominância de questôes de múltipla escolha sobre os conteúdos curriculares, para os concluintes dos cursos. Além desse sistema ter sido imposto à revelia da opinião majoritária de dirigentes e professores universitários e de ser o "Provão" uma prova que não media o aporte do curso para alunos, sua forma de apresentação das médias e do ranking que se estabelecia entre os cursos de cada área prestava-se a muita contestação. Por último, a forma como a imprensa explorava os re- 
sultados desse ranking de cursos e instituições colocou o "Provão" sob forte suspeita de mais servir ao interesse oficial de demonstrar controle sobre o sistema do que de efetivamente avaliá-lo e regulá-lo. O fato é que, após seis anos de aplicação, tendo envolvido na última prova quase duas dezenas de cursos em nível nacional, não houve suspensão ou impedimento de funcionamento de nenhum curso ou instituição.

\section{Modelo de universidade}

Os dados sobre a diferenciação institucional (ver item 2) e a constatação de que, na prática, apenas as universidades com sistemas de pós-graduação consolidados desenvolvem programas de pesquisa e, portanto, cumprem o preceito constitucional da associação ensino-pesquisaextensão, mostram que o modelo largamente predominante e em expansão nesse período foi o aqui denominado modelo de universidade de ensino em detrimento do modelo de universidade de pesquisa. ${ }^{6}$

\section{Legislação educacional}

O esforço de produção de um acervo legislativo ou de marcos regulatórios para o ensino superior durante o período em foco foi considerável. Traduziu, sob muitos aspectos, teses e orientaçõos disseminadas por documentos de organismos multilaterais. O trabalho desenvolvido no Congresso Nacional pelo Poder Executivo levou à aprovação de uma Lei de Diretrizes e Bases da Educação Nacional (LDB, Lei n. 9.394/ 96) de caráter minimalista, cujo capítulo da educação superior apenas traçou linhas gerais para o sistema, deixando para a legislação complementar seu detalhamento. Assim, por meio dos decretos 2.207/97, 2.306/97 e 3.860/01, além da grande diversificação institucional hoje existente, estabeleceu-se uma concessiva interpretação da letra do artigo 207 da Constituição Federal, que estabelece a obediência ao princípio da indissociabilidade entre ensino, pesquisa e extensão.

Por esses decretos, ficaram liberadas da obediência a esse princípio nada menos que 1.024 IES, sobre um total de 1.180 IES, no ano de 2000; apenas as universidades a ele sendo obrigadas. Como na prática não existe nenhuma imposição legal que condicione a aprovação de novas IES à sua organização na forma de universidades, tem-se aqui um elemento importante a garantir a "flexibilização" do suposto modelo único de educação superior (Sguissardi, 2004, p. 43). 
Alguns dos principais mentores dessa legislação principal e complementar têm defendido, desde a década de 1980, a necessidade de flexibilizar o suposto modelo único imposto pela Lei da Reforma Universitária de 1968, que estabelecia a associação ensino-pesquisa e, em caráter preferencial, a criação de IES no formato de universidades. A suposta predominância desse modelo, que de fato sempre foi minoritário, é que estaria engessando o sistema educacional brasileiro e tornando-o muito caro para as possibilidades do Estado nacional.

Pelo Decreto n. 2.306/97, foram reconhecidas as IES privadas com fins lucrativos (empresas comerciais). Esse Decreto foi substituído, em 2001, pelo Decreto n. 3.860/01, que, sobre as entidades mantenedoras das IES privadas, assim estatui:

Art. $3^{\circ}$ - As pessoas jurídicas de direito privado mantenedoras de instituiçôes de ensino superior poderão assumir qualquer das formas admitidas em direito de natureza civil ou comercial, e, quando constituídas como fundação, serão regidas pelo disposto no art. 24 do Código Civil Brasileiro. (Sguissardi, 2004, p. 46 e 47; grifo do autor) ${ }^{7}$

Pelo artigo $6^{\circ}$, as entidades mantenedoras com finalidade lucrativa deverão apenas elaborar, a cada exercício fiscal, demonstrações financeiras atestadas por profissionais competentes (contadores). Não têm mais obrigação, como previsto no Decreto n. 2.306/97, de publicar demonstraçōes financeiras "certificadas por auditores independentes, com o parecer do conselho fiscal ou órgão equivalente", nem de se submeterem, "a qualquer tempo, a auditoria pelo Poder Público" (idem, ibid., p. 47; grifo do autor).

Seja pela drástica redução do financiamento às IFES, seja pelas facilidades de criação de IES privadas, especialmente com finalidade de lucro, explica-se, em grande medida, a pequena expansão do setor público e a grande expansão do setor privado no período.

\section{PNE e vetos presidenciais}

Os vetos presidenciais relativos às metas para a educação superior no Plano Nacional de Educação (Lei n. 10.172, de 9 de janeiro de 2001) são outros indicadores das políticas oficiais em relação ao sistema e o tornam, no dizer de Valente e Romano (2002, p. 97 et passim), uma simples carta de intençôes. 
Mais uma vez, pela mensagem presidencial encaminhada ao Congresso em 9 de janeiro de 2001, ficava-se sabendo que foi a opinião do Ministério da Fazenda que determinou os vetos. Dos nove vetos, quatro referiam-se ao ensino superior. Um deles incidiu sobre a meta que estabelecia que o número de vagas no ensino superior público não poderia ser inferior a $40 \%$ do total desse nível de ensino. Outro incidiu sobre a subvinculação de $75 \%$ dos recursos da União a serem destinados à manutenção, desenvolvimento e expansão das IFES. Foi vetada a meta que propunha a ampliação do financiamento público à pesquisa científica e tecnológica.

Outros vetos indiretamente afetaram o fortalecimento da educação superior pública, uma vez que impediram o aumento do financiamento público da educação. O primeiro deles é o que propunha, no prazo de dez anos, o aumento dos gastos públicos federais, estaduais e municipais para $7 \%$ do PIB, sendo os recursos ampliados à razão de 0,5 nos quatro primeiros anos e de 0,6 nos anos seguintes. Outro eliminou a proposta do PNE de excluir das despesas com manutenção e desenvolvimento do ensino as despesas com pagamento dos aposentados e pensionistas do ensino superior público.

A principal justificativa para os vetos foi o respeito à Lei da Responsabilidade Fiscal, mas, com isso, e porque sem aumento de despesas não há Plano Nacional de Educação, inviabilizou-se um plano que, embora tendo como eixo central algumas diretrizes caras ao FMI e ao BM, dada sua bastante ampla discussão no Congresso, continha princípios e metas que poderiam significar importantes avanços para a educação em geral e para a educação superior em particular.

2. Algumas teses que orientaram as "reformas pontuais" da educação superior no octênio FHC (1995-2002)

As "reformas pontuais", que não dependeram necessariamente de uma lei específica mas de uma série de instrumentos legais e de medidas como a redução dos recursos financeiros, garantidores da mudança, tiveram como pano de fundo os ajustes da economia sugeridos pelo diagnóstico neoliberal e o que se tem denominado como teses defendidas em especial pelo BM ao longo das décadas de 1980 e 1990. 
O fim do século XX pôs a educação superior na berlinda. A ciência e o ensino superior tornaram-se muito mais presentes como fatores de produção e parte integrante da economia, mercadorias ou quasemercadorias, em países centrais, da periferia e da semiperiferia. Da mesma forma que o diagnóstico neoliberal identifica entre as principais causas do fracasso da economia do Estado do Bem-estar sua crescente falta de competitividade, também a educação superior - entendida como parte essencial da economia moderna - necessitaria passar por um choque de competitividade. ${ }^{8}$ Deveria tornar-se um promissor mercado ou quase-mercado de serviços a ser regulamentado no âmbito dos Acordos Gerais é no do Comércio e Serviços (agCS) da Organização Mundial do Comércio (OMC). O reconhecimento legal, no Brasil, das IES com fins lucrativos antecipou a agenda da OMC e, de alguma forma, enfraqueceu a posição (oficiosa) do Brasil, contrária, no âmbito dessa organização, à regulamentação desses serviços. A descoberta desse traço essencial à educação superior (competitividade) permite que se fale nas IES como empresas econômicas a serem administradas de modo empresarial/gerencial.

Pierre Bourdieu (1998) denunciava, no fim da década de 1990, o imperialismo da razão neoliberal a expressar-se de diferentes maneiras. Uma delas, por meio de teses que vão sendo midiaticamente disseminadas pelo planeta. Os planos, relatórios e pareceres de organismos multilaterais, cartilhas como a do Consenso de Washington, relatórios de comissóes nacionais (como o Dearing Report), o Plano Diretor da Reforma do Estado (Brasil, 1995), a legislação e os anteprojetos de lei específicos da educação superior ou de outras áreas das políticas públicas, como a da previdência, e estudos de núcleos de pesquisa de universidades, entre outros, serão seus veículos mais imediatos.

Ao lado de teses que, do ponto de vista da economia ou da administração pública, afetam profundamente as políticas públicas de educação superior - por exemplo, do déficit público, que resultaria da exacerbação do Estado-providência ou do Estado desenvolvimentista -, algumas envolvem diretamente, do ponto de vista da reforma administrativo-gerencial do aparelho do Estado, a questão da educação superior e sua maior ou menor implementação pelo poder público. Dentre essas teses, algumas são destacadas a seguir. 
Tese do maior retorno social e individual dos investimentos em educação básica que o dos investimentos em educação superior

Essa tese está exposta de forma exaustiva e será retomada em documentos posteriores de forma sintética, no documento do BM, de 1986, intitulado Financing education in developing countries - An exploration of policy options (World Bank, 1986).

Objetivando induzir os países em desenvolvimento a investirem seus parcos recursos públicos prioritariamente na educação primária e, posteriormente, na educação secundária, ao mesmo tempo em que recomendava a diminuição dos investimentos públicos na educação superior e a diversificação de suas fontes de recursos (fim da gratuidade e imposição de taxas de matrículas e mensalidades), o documento apresenta o que julga "Considerável evidência (...) acerca do retorno privado e social dos investimentos em educação tanto nos países desenvolvidos como nos em desenvolvimento". (Sguissardi, 2005 b, p. 198) ${ }^{10}$

Ela irá sofrer revisão - com reconhecimento do equívoco teóricoempírico cometido - em documento do Banco, de 2000, intitulado Higher education in developing countries: peril and promise (World Bank, 2000), cuja elaboração é apresentada oficialmente como uma parceria com a Organização das Nações Unidas para a Educação, a Ciência e a Cultura (UNESCO).

Após oito anos da publicação do documento de 1986, essa tese foi retomada no talvez mais importante documento do Banco das duas últimas décadas - Higher education: the lessons of experience (1994). Nele, faz-se o elogio do Chile (de Pinochet), por ter ido muito além das sugestôes do Banco. As reformas desse país, por isso, foram apontadas como exemplo para os demais países. ${ }^{11}$

\section{Tese da universidade de ensino $\mathrm{x}$ universidade de pesquisa}

Neste último documento, faz-se extenso diagnóstico da crise da educação superior, em que o déficit público aparece como conseqüência também do suposto excessivo comprometimento do fundo público com o ensino superior e, especialmente, com as universidades de "modelo europeu" ou universidades de pesquisa (modelo humboldtiano). $\mathrm{O}$ Banco defende, de forma implícita, a universidade de ensino. Desta tese 
decorrem as recomendaçôes de maior diferenciação institucional, "incluído o desenvolvimento de instituições privadas", e a criação de incentivos "para que as instituições públicas diversifiquem as fontes de financiamento, por exemplo, a participação dos estudantes nos gastos e a estreita vinculação entre financiamento fiscal e os resultados" (World Bank, 1994, p. 4 e 29$).{ }^{12}$

\section{Tese do ensino superior como bem antes privado que público}

É exatamente em documento preparado pelo вM, em 1998 (The financing and management of higher education - a status report on worldwide reforms ${ }^{13}$ ), como contribuição para as discussões da Conferência Mundial sobre Educação Superior, organizada pela UNESCO, em Paris, nesse ano, que seria exposta uma tese complementar às duas anteriores, em especial à primeira.

Neste documento, faz-se, antes de tudo, um balanço das reformas no que concerne ao financiamento e à gestão das universidades e demais IES e afirma-se a constatação de um "movimento surpreendentemente homogêneo" nesse processo, mesmo em países de sistemas econômicos e políticos diferentes e vivendo diferentes níveis de desenvolvimento industrial e tecnológico (World Bank, 1998, p. 2). Constata-se o resultado de recomendaçôes presentes em documentos anteriores do Banco: expansão de matrículas e de IES, cada vez mais diferenciadas; redução do custo/aluno; orientações e soluções do mercado; diversificação de fontes ou busca de recursos não-estatais. Identifica-se que essas reformas estariam, então, muito mais "orientadas para o mercado do que para a propriedade pública ou para a planificação e regulação estatais", o que se deve, segundo o Banco, à "crescente importância que em quase todo o mundo têm adquirido o capitalismo de mercado e os princípios da economia neoliberal' (World Bank, 1998, p. 4; grifos nossos).

Esse preâmbulo se fez necessário para a apresentação em grande estilo da tese do ensino superior como bem antes privado que público. Os argumentos são retirados da obra de Nicholas Barr, The economics of the Welfare State (1993, p. 106 e 345), segundo o qual, no dizer do Banco, o ensino superior responderia a muitas das condições identificadas por esse autor como sendo características de um bem privado, "que se pode subordinar às forças do mercado". 
Para o Banco, esse nível de ensino não poderia ser tratado como um "bem estritamente público", em razão de suas condições de competitividade (oferta limitada), excluibilidade (pode-se obtê-lo mediante pagamento) e recusa (não é requerido por todos). Essas características corresponderiam mais a um bem privado do que a um bem público. Além disso, porque os consumidores em geral estariam bem informados a respeito e os provedores, mal informados, estariam dadas "as condições ideais para o funcionamento das forças do mercado" (World Bank, 1998, p. 5).

Diante do quadro apresentado no item 1 e da clareza e funcionalidade dessas teses, no contexto das reformas ultraliberais da economia e da reforma do Estado, não é de estranhar que possam ter fundamentado, de forma explícita ou implícita, as políticas públicas de muitos países e, no caso, das brasileiras. Não é de estranhar que possam ter reforçado e orientado diversas das ações das "reformas pontuais" da educação superior nos últimos anos, tais como:

a) a gradativa desresponsabilização do Estado com o financiamento e a manutenção da educação superior, embora mantendo sobre ela estrito e crescente controle, via sistemas de avaliação, regulação, controle e credenciamento;

b) o estímulo e as facilidades para a criação e expansão de IES privadas sem e com fins lucrativos;

c) a indução a que as IES públicas sejam organizadas e geridas à semelhança de empresas econômicas;

d) a valorização da qualidade acadêmica em moldes administrativo-gerenciais e empresariais: produto, custo/benefício;

e) o incentivo à competição intra e interinstitucional;

f) a manutenção das IFES sem autonomia de gestão financeira e as tentativas de aprovação de instrumentos legais que instituíssem um modelo de autonomia distinto do constitucional, isto é, autonomia financeira em lugar da autonomia de gestão financeira;

g) o implemento à diversificação das fontes de financiamento, mediante, entre outras medidas, a criação de FAIs, a cobrança de mensalidades, contratos de pesquisa com empresas, venda de serviços e consultorias e doaçôes da iniciativa privada; 
h) o implemento à diferenciação institucional - universidades de ensino, em especial -, além de carreira docente por instituição, salários individualizados por volume de aulas e de produção científica (vide GED).

Essas teses parecem estar de fato orientando o trânsito da universidade brasileira - para não dizer latino-americana e mesmo, sob certos aspectos, mundial - do seu funcionamento sob os parâmetros da adaptação ou da superposição dos modelos clássicos de universidade (napoleônico ou humboldtiano) para os dos modelos de ocasião, fundados nessas teses, que podem ser denominados de modelo da "universidade mundial do Banco Mundial" (Aboites, 1996) ou de "modelo anglo-saxão", por sua implantação primeiro na Inglaterra, de Thatcher, e depois também em outros países da antiga Commonwealth, como Austrália, Nova Zelândia e Canadá (Dias, 2003).

\section{A educação superior nos anos Lula (2003-2006)}

Considerada a trajetória do presidente da República eleito e do principal partido de sua base de apoio, e tendo em vista o Plano de Governo para a Educação Superior, a expectativa era de que esta - a Educação Superior - sofresse uma guinada importante no seu processo de desenvolvimento, tendo como pano de fundo uma virada também significativa nos rumos da economia nacional.

$\mathrm{O}$ pano de fundo manteve-se basicamente o mesmo. $\mathrm{Na}$ área universitária, os instrumentos legais e as medidas administrativas, incluídas as financeiras, mostram que até o momento não houve rupturas com o processo anterior, a não ser, em certa medida, na adoção de novo sistema nacional de avaliação, com a recuperação dos montantes de recursos de custeio aos níveis de 1995 e com pequena expansão das IFEs. ${ }^{14}$

Passados três anos e meio, constata-se que não prevaleceram políticas heterodoxas na economia ou antineoliberais em qualquer campo da administração pública, mas, sim, uma clara continuidade das políticas do octênio anterior, tanto no campo da macroeconomia, dos compromissos com o mundo financeiro, quanto nas alianças políticas com partidos de centro e de centro-direita. Isto justificado pela busca da governabilidade. O fiel pagamento da dívida pública (principalmente a externa), com elevação do superávit primário para tanto; as taxas de ju- 
ros básicos, a reforma da Previdência, que feriu interesses de aliados históricos dos mandatários e as concessōes doutrinárias e ideológicas em campos essenciais da administração pública; todos esses fatos revelam que a Carta ao Povo Brasileiro, ${ }^{15}$ de julho de 2002, constituiu-se no efetivo plano de governo (entre eles o da educação superior), em substituição ao plano laboriosamente elaborado para todas as áreas de atuação do governo.

No âmbito das políticas públicas de educação superior, apesar da existência de um capítulo sobre este nível de ensino no Plano de Governo para a Educação (PGE) - Uma escola do tamanho do Brasil -, do qual se ocupou um grupo significativo de especialistas, que o discutiram em dezenas de seminários regionais durante mais de um ano, somente agora, no projeto de Lei da Reforma, ele está sendo parcialmente levado em conta, se excluídas algumas medidas anteriores, como logo acima exposto, além de tempestivas medidas de regulação e controle da expansão do sistema, mormente de seu setor privado (vide Portarias n. $1.217,1.263,1.264,2.477$ e 3.065$)$.

Os compromissos básicos constantes do PGE para a educação superior podem resumir-se em:

a) promoção da autonomia universitária e da indissociabilidade entre ensino, pesquisa e extensão nos termos constitucionais (artigo $207 \mathrm{da} \mathrm{CF}$ );

b) consolidação das instituições públicas como referência para o conjunto das IES do país;

c) expansão significativa da oferta de vagas no ensino superior, em especial no setor público e em cursos noturnos;

d) ampliação do financiamento público ao setor público, revisão e ampliação do crédito educativo e criação de programa de bolsas universitárias, com recursos não-vinculados constitucionalmente à educação;

e) a defesa dos princípios constitucionais da gratuidade do ensino superior público (artigo 206, IV, da CF).

Desses compromissos decorreram 25 propostas, que cobrem um amplo leque de ações e medidas a serem implementadas durante o mandato presidencial 2003-2006. Sob muitos aspectos, retomavam-se as metas do Plano Nacional de Educação (PNE) aprovado no ano anterior 
(2001), tentando-se recuperar o que tinha sido vetado quando de sua sanção presidencial. Comprometia-se o futuro governo, em resumo, a:

1. ampliar as vagas de forma compatível com a meta de 30\% da faixa etária até o ano 2011 e atingir, no médio prazo, uma proporção de $40 \%$ das matrículas no setor público;

2. promover a autonomia nos termos constitucionais, incluindo a escolha dos dirigentes;

3. resolver a questão da desigualdade da oferta regional de vagas na graduação e pós-graduação e buscar melhor oferta de cursos e vagas em áreas de conhecimento que melhor respondam às necessidades do projeto nacional de desenvolvimento;

4. modificar o sistema de seleção, com atenção para as minorias raciais e socioeconômicas (cotas);

5. substituir o sistema de avaliação vigente ("Provão");

6. revisar carreiras e matrizes salariais de docentes e funcionários técnico-administrativos das IFEs;

7. ampliar a supervisão, pelo poder público, da oferta e expansão dos serviços públicos de educação superior prestados por IES públicas e privadas, aperfeiçoar e aplicar a atual legislação sobre reconhecimento ou renovação da condição de universidade atribuída às IES públicas ou privadas, com base em procedimentos definidos pelo sistema nacional de avaliação institucional, e redefinir os critérios para autorização de funcionamento de novos cursos, para reconhecimento dos cursos autorizados e em funcionamento e para credenciamento e recredenciamento das IES;

8. estabelecer novo marco legal para as FAIs criadas nas IES públicas, regulamentando suas atribuições na prestação de serviços, de modo a garantir seu estrito controle e o retorno dos recursos financeiros e patrimoniais auferidos em suas atividades à respectiva IES, e impedir sua utilização por interesses de indivíduos ou grupos.

Em relação ao financiamento da educação superior, não houve proposta de um índice sobre o PIB, por exemplo, ou sobre a verba orçamentária destinada ao MEC, mas houve o compromisso de, reexaminados os vetos ao PNE, buscar-se aumentar gradativamente os gastos com educa- 
ção, de modo a atingir-se, no prazo de dez anos, no mínimo o índice de $7 \%$ do PIB, conforme meta vetada desse plano.

Como já apontado, algumas dessas propostas estão sendo visadas no projeto de lei da reforma da educação superior encaminhado ao Congresso Nacional. Portanto, o plano de governo para a educação superior teria servido muito parcialmente como diretriz das açóes oficiais nessa área até o presente.

Cabe observar aqui algumas medidas, especialmente do ponto de vista legal, que marcam as açōes federais no setor no período em pauta.

O momento atual, marcado pelo processo de elaboração do projeto de lei da reforma da educação superior, foi antecedido, no Governo Lula, por quatro leis e um decreto (decreto-ponte), que (as leis) apontam mais para a continuidade do que para descontinuidade das políticas anteriores no setor e que, direta ou indiretamente, condicionam ou limitam os eventuais avanços dessa futura lei, que possuiria, entre seus objetivos, o fortalecimento do setor público e a regulação do sistema, em especial em seu setor privado/mercantil.

A Lei n. 10.861, de 14 de abril de 2004, criou o SINAES. Pretendeu-se, com essa lei, a superação dos conhecidos limites do Exame Nacional de Cursos ("Provão") por um sistema muito mais complexo de ações de avaliação, entre as quais duas provas, uma na entrada e outra na saída do sistema, realizadas por amostragem. $\mathrm{O}$ novo sistema teria trazido avanços inegáveis, mas, ainda assim, é questionado porque não respeitaria a autonomia universitária e seria centralizador no que tange à constituição da Comissão Nacional de Avaliação do Ensino Superior (CONAES), responsável pelas principais diretrizes e normas relativas ao sistema. Sua eficácia está em processo de prova, com sua aplicação em andamento.

A Lei n. 10.973 (Lei de Inovação Tecnológica), vinculada ao Ministério de Ciência e Tecnologia, de 2 de dezembro de 2004, trata dos incentivos à inovação e à pesquisa científica e tecnológica no ambiente produtivo. Essa lei cria facilidades para a utilização dos recursos - físicos, materiais e humanos - das universidades pelas empresas, assim como a transferência de tecnologia daquelas para estas. Viabiliza a alocação de recursos públicos para empresas nos projetos ditos de inovação. Prevê a gratificação dos pesquisadores cujos conhecimentos venham a ser utilizados por empresas. A principal crítica que lhe é feita é de que, justificada pela necessidade de aproximação universidade-empresa, criaria sérios riscos de 
distorção da verdadeira função pública da universidade no campo científico e da inovação e, dada a penúria financeira das universidades públicas e seus docentes/pesquisadores, criaria também facilidades para a subordinação da agenda universitária ao campo empresarial, limitando a liberdade acadêmica e aprofundando o fenômeno da heteronomia universitária, um dos traços da universidade hoje em muitos países.

A Lei n. 11.079, de 30 de dezembro de 2004, institui normas gerais para licitação e contratação de parceria público-privada (PPP) no âmbito da administração pública. Essa lei prevê a parceria do Estado com empresas privadas, nas mais diferentes áreas da produção, comércio de bens e serviços de natureza pública e coletiva, isto é, pesquisa, desenvolvimento tecnológico, meio ambiente, patrimônio histórico e cultural, e serviços de educação e ensino. ${ }^{16}$ Permite a outorga de recursos públicos à administração de entes privados. Como contrapartida do ente privado, requer-se não mais do que $30 \%$ do valor do empreendimento, com todas as salvaguardas oficiais. Justificariam essa lei a baixa capacidade de investimento estatal e a suposta superioridade gerencial privada. A crítica principal, no caso da educação, é que, para além do fortalecimento do pólo privado do Estado ou como parte dele, amplia-se a utilização dos recursos públicos por entidades privadas, com ou sem fins lucrativos.

Finalmente, a Lei n. 11.096, de 13 de janeiro de 2005, instituiu o Programa Universidade para Todos (PROUNI). Essa lei regula a atuação de entidades beneficentes de assistência social no ensino superior. O programa, pretextando a "publicização" do privado, na forma como foi aprovado e está sendo implementado, fortalece as instituiçōes privadas comerciais de ensino. Pode-se entendê-la como uma forma de aplicação lato sensu do espírito das PPPs no campo do ensino superior. Em troca da isenção de um conjunto de impostos pelas IES privadas (o programa é muito mais interessante para as instituiçôes com fins lucrativos), aprovou-se a possibilidade de troca de cerca de $10 \%$ das vagas ou $8,5 \%$ da receita bruta, na forma de bolsas para alunos egressos de escolas públicas, entre outros.

A atuação dos lobbies do ensino superior privado/comercial, quando da tramitação da medida provisória no Congresso Nacional, acabou por modificar a seu favor a proposta oficial que, ao início, era mais exigente maior percentual de vagas e de receita por idêntico montante de impostos -, o que tornava essas vagas menos onerosas que as das universidades federais, por exemplo, embora dessa operação saísse fortalecido exatamente o 
setor privado que mais se expandiu nos últimos anos, isto é, o com fins lucrativos. ${ }^{17}$ Cálculos financeiros indicam que, com as modificações atuais, o custo dessas vagas em IES privadas - que priorizam as atividades de ensino e apresentam em geral baixa qualidade - tornou-se maior do que o seria para o Tesouro Nacional nas universidades públicas, que priorizam atividades de ensino e pesquisa e são, via de regra, de melhor qualidade. A utilização dos espaços ociosos dos campi das IFES teria sido muito menos onerosa e cumpriria parte de um dos compromissos do plano de governo para a educação superior.

Dentre as medidas que visam conectar a avaliação e a regulação, destaca-se a edição de um longo (76 artigos) Decreto, o de n. 5.773, de 9 de maio de 2006, que "Dispõe sobre o exercício das funções de regulação, supervisão e avaliação de instituições de educação superior e cursos superiores de graduação e seqüenciais no sistema federal de ensino". Este decreto, dada a presumível demora na aprovação do Projeto de Lei da Reforma enviado ao Congresso Nacional, visaria antecipar algumas de suas principais medidas. Dentre estas, a incorporação do Exame Nacional de Desempenho dos Estudantes (ENADE), parte do SINAES, no processo de reconhecimento e renovação de reconhecimento dos cursos; a extensão aos conselhos profissionais da possibilidade de se manifestarem a respeito desse processo de reconhecimento de cursos; a melhor definição de competências na aprovação de instituições e de cursos, aquelas ficando sob responsabilidade do Conselho Nacional de Educação e estes da SESU/MEC e SETEC/MEC.

As medidas administrativas, especialmente em relação à abertura e ao credenciamento de cursos e novas IES, foram importantes formas de implementação do plano de governo. $\mathrm{O}$ mesmo se pode dizer da criação de sete novas universidades federais e de 32 novos campi como forma de expansão das IFEs e das vagas no setor público (federal). Entretanto, no que concerne ao financiamento, nó górdio da questão universitária, o montante de recursos financeiros destinados às instituiçôes federais, reduzidos de $0,91 \%$ a cerca de $0,60 \%$ do PIB no octênio anterior, mantevese praticamente inalterado durante os primeiros anos deste governo, ${ }^{18} \mathrm{a}$ menos da recuperação das verbas de custeio.

\section{Projeto de lei da reforma da educação superior: perspectivas}

Como já dito, o projeto de lei da reforma da educação superior (Brasil, 2006), mesmo que aprovado nos termos de sua versão encami- 
nhada ao Congresso Nacional, não comportará toda a reforma, que é um longo e denso processo, impossível de ser enfeixado numa única lei. Essa lei seria a última e importante etapa desse processo, sob certos aspectos, de continuidade, sob outros, de ruptura.

Esse projeto distingue-se da legislação em vigor, antes de tudo, como já dito, pelo processo de quase dois anos de discussão coordenada pelo MEC até sua terceira versão, tendo como interlocutores a comunidade acadêmico-científica, entidades de dirigentes universitários do setor público e do setor privado, entidades empresariais e de trabalhadores e movimentos sociais urbanos e rurais. Para esta quarta versão (da Casa Civil), encaminhada ao Congresso Nacional, os principais interlocutores parecem ter sido o Ministério da Fazenda e do Planejamento (mão direita do Estado, na expressão de Bourdieu), do que teria decorrido sensível redução dos já pouco animadores avanços da versão anterior em relação tanto à questão da autonomia, quanto à do financiamento das IFES.

O grande eixo da versão anterior (terceira), do fortalecimento do setor público federal - pela via da autonomia de gestão financeira e financiamento, ainda que em condições bastante precárias - não é retomado nos mesmos termos na quarta versão, como se verá. A ênfase, nesta versão, mais do que na autonomia e no financiamento estaria posta na organização e nos marcos regulatórios do sistema federal de educação superior, público e privado, correspondendo, pois, apenas parcialmente aos princípios e metas do Plano de Governo para esse nível da educação.

A regulação e o controle do sistema federal público e privado, que se darão pelo Sistema Nacional de Avaliação da Educação Superior (SINAES), já em fase de implantação, pelas normas muito mais rígidas quanto a credenciamento e recredenciamento de cursos e instituiçóes, assim como com o estabelecimento de critérios muito mais exigentes em relação ao vínculo institucional e à qualificação dos docentes das IES universidades, centros universitários e faculdades, respondem a preocupaçōes relativas principalmente às IES de natureza privado/mercantil.

A mais controversa das questôes postas pelo projeto é a do financiamento da educação superior pública federal. Ela está presente no artigo 43, em que se estabelece que "Durante o período de dez anos a partir da publicação desta Lei, a União aplicará, anualmente, nas instituições federais de ensino superior vinculadas ao Ministério da Educação, nunca menos do equivalente a setenta e cinco por cento da receita constitucionalmente vinculada à manutenção e desenvolvimento do ensino" (art. 43, caput). 
Constitui-se um avanço a definição desse percentual. Entretanto, os recursos resultantes disso se revelariam ainda insuficientes para as necessidades das IFES, mesmo com a prevista exclusão desse cálculo de um conjunto de recursos, receitas e despesas, tais como:

I - os recursos alocados às instituições federais de ensino superior por entidades públicas de fomento ao ensino e à pesquisa científica e tecnológica e por suas congêneres privadas;

II - os recursos alocados às instituições federais de ensino superior mediante convênios, contratos, programas e projetos de cooperação, por órgãos e entidades públicas de qualquer nível de governo, bem como por organizaçóes internacionais;

III - as receitas próprias das instituições federais de ensino superior, geradas por suas atividades e serviços; e

IV - as despesas com inativos e pensionistas das instituiçôes federais de ensino superior, sem prejuizo de seus direitos específicos;

$\mathrm{Na}$ versão anterior (terceira, do $\mathrm{MEC}$ ), excluíam-se também: 1) as despesas que não se caracterizem como de manutenção e desenvolvimento do ensino; 2) as despesas referentes a açōes e serviços públicos de saúde promovidos pelos hospitais vinculados às instituições federais de ensino, contabilizadas para efeito do cumprimento do disposto no artigo 198, $\$ 2^{\circ}$ da Constituição Federal e artigo 77 do Ato das Disposiçóes Constitucionais Transitórias; e 3) as despesas com pagamentos de débitos judiciais originados em legislação vigente no período anterior à promulgação desta Lei, ou que resultem de atos posteriores que não tenham decorrido de decisão emanada das instituiçôes federais. (art. 49, itens IV, VI e VII). Da atual versão também não consta o que previa o $\$ 3^{\circ}$ do artigo 49 , isto é, "Os excedentes financeiros de cada exercício, a qualquer título, serão automaticamente incorporados ao exercício seguinte, sem prejuízo do previsto no caput".

Se, com as exclusões de cálculo da versão anterior, os recursos já eram considerados insuficientes para as necessidades das IFES, o que dizer do proposto na versão atualmente em tramitação no Congresso $\mathrm{Na}$ cional? Que as perspectivas são ainda menos promissoras para a manutenção das IFES, recuperação do déficit acumulado nos últimos 16 anos - quando os recursos destinados à manutenção das IFES reduziram-se gradativamente de $0,97 \%$ a cerca de $0,50 \%$ do PIB -, que provocou o "sucateamento" dos campi das federais, e para cobrir as necessidades fi- 
nanceiras exigidas pela expansão tanto em andamento quanto prevista pelo Plano de Governo. Este, com base no que originalmente era previsto no PNE, determina que, no médio prazo, se eleve o total de matrículas no setor público da educação superior a $40 \%$ do total de matrículas do sistema, que, por sua vez, deverá alcançar o índice de $30 \%$ da faixa etária de 18 a 24 anos. Isso significa multiplicar por três a atual população universitária brasileira e por cinco a do setor público.

É importante também sinalizar o que estabelece o $\$ 2^{\circ}$ desse artigo, isto é, que "A aplicação de que trata o caput será apurada a cada quatro anos, a partir da publicação desta Lei”. Primeiro, parece duvidar-se da estrita aplicação da Lei; segundo, se isto deve ser feito, não deveria sê-lo desde o primeiro ano de vigência da Lei e anualmente?

Diferentemente da versão anterior, não se faz menção a qualquer percentual do orçamento a ser aplicado em despesas de custeio e capital, excluídas as despesas de pessoal, apesar do avançado sucateamento de edifícios e laboratórios da maioria das IFES.

Sobre a questão do financiamento das IFES, é importante destacar a não-extinção das polêmicas fundações de apoio institucional, vistas por seus opositores, em geral preocupados com a natureza pública das IES apoiadas, como uma forma velada, mas muito eficaz, de privatização do espaço público e de implementação da autonomia financeira (Sguissardi, 2002b). A extinção era proposta na primeira versão desse anteprojeto. Sob pressão, em especial dos dirigentes das IFES, por meio de sua associação nacional (ANDIFES), houve recuo oficial a partir da segunda versão. $\mathrm{Na}$ atual versão desaparecem as salvaguardas presentes na terceira, que visavam garantir o controle das IES apoiadas sobre o funcionamento dessas organizaçóes privadas, quando, no artigo 61, das Disposições Transitórias, previa-se alteração na Lei n. 8.958, de 20 de dezembro de 1994 , mediante adendo de um parágrafo ao seu artigo $2^{\circ}$, nos seguintes termos:

Parágrafo único. São condiçôes para credenciamento e renovação de credenciamento de que trata o inciso III:

I - estatuto referendado pelo conselho superior da instituição apoiada;

II - órgão deliberativo superior da fundação integrado por no mínimo um terço de membros designados pelo conselho superior da instituição apoiada; $\mathrm{e}$

III - demonstraçôes contábeis do exercício social, acompanhadas de parecer de auditoria independente, bem como relatório anual de gestão, enca- 
minhados ao conselho superior da instituição apoiada para apreciação, em até sessenta dias após a devida aprovação pelo órgão deliberativo superior da fundação.

O risco de açôes que lesem o patrimônio público das IFEs existe e talvez não compensem no longo prazo as eventuais vantagens da existência dessas fundaçôes. A autonomia universitária a ser garantida por essa lei deveria poder comportar e garantir as ações, atualmente necessárias, dessas fundações, quando as IFES ainda se encontram privadas do efetivo usufruto do estatuto da autonomia. Se, com o implemento da autonomia por essa futura lei, ainda persistirem obstáculos à plena participação das IFES autônomas em operações administrativo-financeiras, que hoje somente as fundações têm condições de executar e que sejam imprescindíveis à manutenção e funcionamento das IFES, talvez seja muito mais recomendável a abolição desses entraves por meio de lei específica do que a convivência com os riscos anteriormente mencionados.

Como dito anteriormente, tem lugar de destaque no projeto o tema da regulação da educação superior no sistema federal de ensino. A ele são dedicados muitos artigos detalhando a função regulatória da União e os mecanismos a serem utilizados para tanto, entre os quais os que articulam as ações de avaliação do SINAES e as medidas de pré-credenciamento, credenciamento e recredenciamento das IES, e de autorização de cursos.

Resta saber se o SINAES (e a CONAES) terá sucesso na sua delicada fase de implantação gradativa do sistema de avaliação e se haverá de se impor como critério e âncora dessa imprescindível função regulatória de um sistema que, em especial, em sua face privada e comercial, até o momento viu-se muito pouco escorado em critérios de qualidade na sua rápida e incontrolada expansão.

O projeto, embora anunciando preocupação dos proponentes com a democratização interna da gestão das IFES - autonomia na indicação dos dirigentes - e também com a democratização do acesso, incluindo, pela primeira vez, numa lei de reforma da educação superior, questôes polêmicas como a das denominadas ações afirmativas ou de inclusão social, retrocede em relação à versão anterior, quanto à escolha de dirigentes. Em seus artigos 40 e 41, respectivamente, estabelece a livre nomeação de reitor de universidade e de diretor de centro universitário pelo Presidente da República, "mediante escolha em lista tríplice eleita diretamente pela comunidade acadêmica, na forma do estatuto". 
Mas, exatamente por se tratar de questão polêmica, as determinações legais restringem-se ao âmbito das IFEs. O mesmo vale para a assistência estudantil, a que essas instituições oficiais serão obrigadas a destinar no mínimo 9\% de sua verba de custeio ( $\$$ único do artigo 47).

Dada a questão polêmica, já referida neste estudo, da proposta incluída na_agenda do Acordo Geral de Comércio e Serviços (AGCS), da OMC, de regulamentação dos serviços educacionais, em relação à qual o Brasil ter-se-ia manifestado contrário, porque a educação é um bem público de interesse nacional, causa estranheza que, no $\$ 4^{\circ}$ do artigo $7^{\circ}$, das Disposições Gerais, se reconheça e permita a participação do capital estrangeiro nas entidades mantenedoras de IES privadas comerciais. Isso está explícito no anteprojeto ao se estabelecer que "pelo menos $70 \%$ (setenta por cento) do capital votante das entidades mantenedoras de instituição de ensino superior, quando constituídas sob a forma de sociedade com finalidades lucrativas, deverá pertencer, direta ou indiretamente, a brasileiros natos ou naturalizados". Faz pequeno contrapeso a essa concessão às propostas da agenda do AGCS da OMC a proibição da franquia no sistema de educação superior no país, estabelecida pelo $\$ 5^{\circ}$ desse mesmo artigo.

A diferenciação institucional, tão incentivada nas "recomendações" do Banco Mundial, é minorada, quando, no artigo 90, as IES são classificadas em universidades, centros universitários e faculdades.

Todas as IES do sistema deverão observar um conjunto de diretrizes, cujas conseqüências para sua não-observância não estão muito claras na lei. Entre outras diretrizes constantes do artigo 11, podem ser destacadas as seguintes:

I - implementação de planos de carreira, bem como de capacitação e treinamento, para docentes e pessoal técnico e administrativo;

II - divulgação pública de critérios de seleção para admissão de docentes e pessoal técnico e administrativo;

III - avaliação institucional interna e externa, abrangendo seus cursos e programas, e assegurada, na avaliação interna, a participação de docentes, estudantes, pessoal técnico e administrativo e representantes da sociedade civil;

IV - organização colegiada, garantindo a prevalência da representação docente;

Cada tipo de IES deverá, para fazer jus a sua denominação - universidade, centro universitário e faculdade -, obedecer a alguns requi- 
sitos mínimos, em grau de exigência decrescente. Da universidade exige-se, entre outros:

I - estrutura pluridisciplinar, com oferta regular, em diferentes campos do saber, de pelo menos dezesseis cursos de graduação ou de pós-graduação stricto sensu, todos reconhecidos e com avaliaçâao positiva pelas instâncias competentes, sendo, pelo menos, oito cursos de graduação, três cursos de mestrado e um curso de doutorado; (...)

III - um terço do corpo docente em regime de tempo integral ou dedicação exclusiva, majoritariamente com titulação acadêmica de mestrado ou doutorado;

IV - metade do corpo docente com titulação acadêmica de mestrado ou doutorado, sendo pelo menos metade destes doutores; e

$\mathrm{V}$-indissociabilidade entre ensino, pesquisa e extensão. (art. 12; grifos nossos)

Enfatize-se igualmente o esforço de explicitar tanto as atividadesfim da universidade como sua indissociabilidade (artigo 13):

A universidade, no exercício de sua autonomia, deve promover concomitantemente:

I - geração de conhecimentos, tecnologias, cultura e arte;

II - disseminação e transferência de conhecimentos e tecnologias, preservação e difusão do patrimônio histórico-cultural, artístico e ambiental;

III - formação acadêmica e profissional em padrōes de qualidade reconhecidos nacional e internacionalmente; $\mathrm{e}$

IV - articulação com a sociedade, visando contribuir por meio de suas atividades de ensino, pesquisa e extensão para o desenvolvimento educacional, socioeconômico e ambiental sustentável de sua região.

As exigências para os centros universitários são proporcionalmente menores; para as faculdades são ainda menores do que as cobradas aos centros (mínimo de um quinto dos docentes com mestrado ou doutorado em efetivo exercício docente).

A atualização no tempo dessas exigências é proposta como atribuição das Conferências Nacionais de Educação Superior a serem realizadas no mínimo a cada quatro anos. Essas conferências teriam também a atribuição de rever os parâmetros de financiamento das IFES (art. 51).

A principal observação crítica a ser feita é que, apesar da enorme diferença quanto ao grau de exigência requerido das universidades e das 
faculdades, por exemplo, a validade dos diplomas e certificados concedidos por umas e outras será legalmente a mesma em todo o território nacional.

\section{Considerações finais}

Se o país não estivesse vivendo a crise política - do governo e do seu principal partido - que fragiliza inegavelmente sua base de apoio no Congresso Nacional e não fossem tão fortes os interesses do setor privado comercial da educação superior ali representados, talvez fosse correto prever a aprovação de uma lei que, com todas as suas eventuais limitações, pudesse significar alguma ruptura com o processo de reforma da educação superior em curso nesta última década.

Entretanto, a crise existe e são muito profundas as marcas de um sistema universitário, no Brasil, caracterizadamente neoprofissional, em que mais de $90 \%$ das instituiçōes se identificam como instituições ou universidades apenas de ensino. É forte a tendência de que mesmo as universidades que desenvolvem traços nítidos do modelo humboldtiano ou de pesquisa, tendo em vista a penúria de verbas e os baixos salários, estejam se tornando universidades heterônomas, isto é, cuja agenda de pesquisa e de criação de novas carreiras obedeça cada vez mais a interesses externos vinculados a prioridades do mercado ou de agências que valorizam certo tipo de pesquisa operacional, muito mais do que a pesquisa básica ou de áreas não valoradas do ponto de vista mercantil. São cada vez mais evidentes as marcas da competição no campo científico-acadêmico, primeiro, em razão da gratificação de estímulo à docência (GED), desativada desde 2003; segundo, pelo produtivismo acadêmico engendrado em especial pelo Modelo CAPES de Avaliação; terceiro, pela disputa acirrada entre docentes/pesquisadores pelos recursos, sempre insuficientes, destinados à ciência e tecnologia. Finalmente, é grande o peso das estruturas vigentes na educação superior no país, fortalecidas por "reformas pontuais" por intermédio de legislação específica do período FHC e também do período Lula da Silva. Essa legislação não se revoga de um dia para outro, nem se desfazem e superam as estruturas que nelas se apóiam, porque uma nova lei, propondo alguma ruptura do processo vigente, foi aprovada.

Diante disso, pode-se levantar como hipótese plausível que são pequenas as chances desse projeto de lei ser aprovado pelo atual Congresso

Educ. Soc., Campinas, vol. 27, n. 96 - Especial, p. 1021-1056, out. 2006

Disponível em <http://www.cedes.unicamp.br> 
Nacional, e ainda mais remotas as chances de que venha a sê-lo sem alteraçôes importantes propostas pelos representantes dos interesses contrariados, isto é, os que vêem nessa eventual futura lei um instrumento à disposição do Estado para promover o fortalecimento, ainda que limitado, do setor público e para regular em especial o setor privado comercial. A perspectiva de diminuição das facilidades de expansão do privado, com fins lucrativos, isto é, de redução da lucratividade dos negócios no quase-mercado da educação superior, tenderá a ser o motor da desqualificação desse projeto que, ainda que de forma bastante limitada, pretendeu contrapor-se à universidade mundial da globalização ou ao modelo anglo-saxão neopragmático e eficientista.

\section{Recebido e aprovado em setembro de 2006.}

\section{Notas}

1. Para esses dados contextuais, retomamos no essencial o que consta em Sguissardi (2002a, p. 25 e 26).

2. Segundo dados do Banco Mundial, já em 1994 o Brasil situava-se entre os países do mundo com maior taxa de privatização da educação superior, no extremo oposto de países como França, Alemanha, Estados Unidos, Tailândia, México, Venezuela, Argentina, Honduras, Bolívia, Itália, Espanha, Quênia, Panamá, Áustria, Suécia, Paquistão, cujo montante de matrículas garantidas pelo fundo público é superior a 75\% (World Bank, 1994).

3. O caso do Distrito Federal deve ser registrado. Em 2000, contava com cerca de 40 IES, mas com uma única pública (a UNB) e 39 privadas, das quais 37 particulares ou privadas stricto sensu. Nesse ano, as vagas oferecidas foram 32.251, das quais apenas 3.904 (12\%) públicas e $28.347(88 \%)$ privadas: 3.910 (14\%) de IES comunitárias e/ou confessionais e 24.437 (86\%) de IES particulares ou privadas stricto sensu.

4. Para mais informações sobre a redução do financiamento das IFES, ver Sguissardi (2005b) e, em especial, Amaral (2003).

5. No ano de 2001, as FAIs eram 96 nas IFES, com um crescimento de $129 \%$ em relação ao ano de 1995. (Amaral, 2003, p. 183). Para mais informações sobre as FAIs, ver Sguissardi (2002b).

6. Para maior aprofundamento dessa questão, ver Sguissardi (2004).

7. O artigo 7o do Decreto n. 2.306/97 reconhecia as IES privadas stricto sensu e assim as definia: "As instituiçôes privadas de ensino, classificadas como particulares em sentido estrito, com finalidade lucrativa, ainda que de natureza civil, quando mantidas e administradas por pessoa física, ficam submetidas ao regime da legislação mercantil, quanto aos encargos fiscais, parafiscais e trabalhistas, como se comerciais fossem, equiparados seus mantenedores e administradores ao comerciante em nome individual".

8. Os objetivos da utilidade, da eficiência e da eficácia do empreendimento educativo, retomados à outrance hoje pelos ultraliberais, já estavam presentes na obra clássica de Adam Smith, A riqueza das nações (1983). 
Valdemar Sguissardi

9. A autoria é atribuída a Georg Psacharopoulos, Jee-Peng Tan e Emmanuel Jimenez, com colaboradores.

10. Para uma mais aprofundada análise dessa e demais teses, e suas conseqüências, que serão apresentadas neste texto, ver Sguissardi (2005b).

11. O Chile é elogiado, entre outras razões, por ter reduzido os gastos estatais com a educação superior. "No mesmo período, a parte do gasto público destinada à educação superior, como porcentagem do PIB, diminuiu de 1,65 a 0,45\%" (World Bank, 1994, p. 33). A retomada dessa tese explicita-se em afirmações como: "No entanto, no setor de educação há provas de que as inversōes no nível terciário têm taxas de rentabilidade social mais baixas que as inversōes no ensino primário e secundário (...).” (World Bank, 1994, p. 14).

12. Como se viu em páginas anteriores, a partir de 1994, no caso do Brasil, recrudesce o processo de redução de gastos públicos federais para as IFEs e de expansão da privatização desse nível de ensino.

13. O documento é atribuído ao consultor D. Bruce Johnstone (da Universidade de Buffalo, Estados Unidos), com a colaboração de Alka Arora e William Experton.

14. Universidades Federais do $\mathrm{ABC}$, do Recôncavo da Bahia, do Triângulo Mineiro, da Grande Dourados, de Alfenas, Rural do Semi-Árido, dos Vales do Jequitinhonha e Mucuri, e Universidade Tecnológica do Paraná (Brasil. Exposição de Motivos n. 015, MEC/MF/MP/MCT, $10 / 04 / 2006 b)$.

15. Na Carta, alguns compromissos se destacam: plano de governo que se sustente na redução da vulnerabilidade externa, em reformas estruturais (tributária, agrária, previdenciária e trabalhista), no combate à fome, à insegurança pública e ao déficit habitacional; 2 . governabilidade via coalizão nacional, que implica processo exaustivo de negociação, alianças, pacto social e crescimento com estabilidade; respeito aos contratos e obrigações do país, e não ao calote na dívida externa e política austera de controle do endividamento público; segurança dos investidores não-especulativos; controle inflacionário; equilíbrio fiscal; superávit primário, visando à capacidade de honrar compromissos (ver Sguissardi, 2005a).

16. "Art. $2^{\circ}, \$ 2^{\circ}$ - Concessão administrativa é o contrato de prestação de serviços de que a Administração Pública seja a usuária direta ou indireta, ainda que envolva execução de obra ou fornecimento e instalação de bens”.

Em tese, e a princípio, a definição acima permite conceder/delegar ao setor privado a produção e o fornecimento de bens e serviços públicos de uso gratuito, o que significa uma área de abrangência bastante ampla: manutenção do patrimônio histórico e cultural, serviços de educação e de saúde em estabelecimentos públicos, preservação do meio ambiente, saneamento básico, funçôes de pesquisa e de desenvolvimento tecnológico em laboratórios públicos, por exemplo, entre outras atividades. Serviços dos quais o Estado é o usuário direto, como os serviços de informática, também poderão ser objeto de concessão administrativa sempre que abrangerem mais do que o simples fornecimento de mão-de-obra, tiverem valor superior a R \$ 20 milhôes e prazo contratual superior a cinco anos (exigências gerais de todo projeto de concessão em parceria)" (Juruá, 2005, grifos nossos).

17. Para mais informaçôes e análises sobre o significado do PROUNI no âmbito das finanças públicas e da renúncia fiscal, ver Carvalho e Lopreato (2005).

18. Dados fornecidos por Vera Flores, coordenadora da assessoria de comunicação do Ministério da Educação, em carta ao Painel dos Leitores do jornal Folha de S.Paulo, em 25 de agosto de 2005 .

Educ. Soc., Campinas, vol. 27, n. 96 - Especial, p. 1021-1056, out. 2006

Disponível em <http://www.cedes.unicamp.br> 


\section{Referências bibliográficas}

ABOITES, H. Banco Mundial y universidad: el fin de la autonomia, el comienzo del cogobierno. Reunión de Análisis de las Ciencias, la Educación y la Cultura. Cuernavaca, Morelos, México, 13 jul. 1996. Disponível em: <http://www.smf.mx/boletin/Jul-96/articles/banco.html>. Acesso em: 10 ago. 1996.

AMARAL, N. C. Financiamento da educação superior: Estado x mercado. São Paulo: Cortez, 2003.

BARR, N. The economics of Welfare State. 2. ed. Londres: Weidenfeld and Nicholson, 1993.

BOLOGNA DECLARATION, 1999. Documento disponível em: <http:/ /europa.eu.int/comm/education/policies/educ/bologna/bologna_en.html>. Acesso em: out. 2004.

BOURDIEU, P. Contre-feux: propôs pour servir à la résistance contre l’invasion neo-libéral. Paris: Líber, 1998.

BRASIL. Casa Civil da Presidência da República. Projeto de Lei da reforma da educação superior. Brasília: Casa Civil, abr. 2006a.

BRASIL. Casa Civil da Presidência da República. Exposição de Motivos. Projeto de Lei da reforma da educação superior. Brasília: E.M.I n. 015 /MEC/MF/MP/MCT. 10 abr. 2006b.

BRASIL. Decreto n. 2.207, de 15 de abril de 1997. Regulamenta, para o Sistema Federal de Ensino, as disposições contidas nos arts. 19, 20, 45, 46 e $\$ 12$, 52, parágrafo único, 54 e 88 da Lei n. 9.394, de 20 de dezembro de 1996, e dá outras providências. Diário Oficial da Uniāo, Brasília, 16 abr. 1997. Seção 1, p. 7534.

BRASIL. Decreto n. 2.306, de 19 de agosto de 1997. Regulamenta, para o Sistema Federal de Ensino, as disposições contidas no art. 10 da Medida Provisória n. 1.477-39, de 8 de agosto de 1997, e nos arts. $16,19,20,45,46$ e $\$ 1^{\circ}, 52$, parágrafo único, 54 e 88 da Lei no 9.394, de 20 de dezembro de 1996, e dá outras providências. Diário Oficial da União, Brasília, 20 ago. 1997, n. 159. Seção 1, p. 17991

BRASIL. Decreto n. 3.860, de 9 de julho de 2001. Dispõe sobre a organização do ensino superior, a avaliação de cursos e instituições, e 
dá outras providências. Diário Oficial da União, Brasília, 10 jul. 2001.

BRASIL. Lei n. 8.958, de 20 de dezembro de 1994. Dispõe sobre as relações entre as instituições federais de ensino superior e de pesquisa científica e tecnológica e as fundações de apoio e dá outras providências. Diário Oficial da União, Brasília, 21 dez. 1994. Seção I, p. 1.

BRASIL. Lei n. 9.394, de 20 de dezembro de 1996. Estabelece as diretrizes e bases da educação nacional. Diário Oficial da Uniāo, Brasília, ano CXXXIV, n. 1.248, 23 dez. 1996. p. 27833-27841.

BRASIL. Lei n. 10.172, de 9 de janeiro de 2001. Plano Nacional de Educação - PNE. Diário Oficial da União, Brasília, 10 jan. 2001.

BRASIL. Ministério da Educação. Anteprojeto de Lei da reforma da educação superior. Brasília: Ministério da Educação, jul. 2005.

BRASIL. Ministério da Fazenda. Secretaria de Política Econômica. Gasto social do governo federal: 2001 e 2002. Brasília: Ministério da Fazenda, nov. 2003.

BRASIL. Ministério do Planejamento. Plano Diretor da Reforma do Estado. Brasília: Ministério do Planejamento, nov. 1995. Disponível em: <http://www.planejamento.gov.br/gestao/conteudo/publicacoes/ plano_diretor/portugues.htm>. Acesso em: 5 dez. 2005.

CARVALHO, C.H.A.; LOPREATO, F.L.C. Finanças públicas, renúncia fiscal e o PROUNI no Governo Lula. Impulso, Piracicaba, v. 16, n. 40, maio/ago. 2005. (Dossiê Educação \& Política).

CHAUI, M. A universidade operacional. Folha de S. Paulo, São Paulo, Caderno Mais!, p. 3, 9 maio 1999.

DIAS, M.A.R. Produção, partilha e apropriação do conhecimento. In: SEMINÁRIO Internacional Universidade XXI. Brasília, nov. 2003.

DIEESE. Anuário dos trabalhadores: 2000-2001. São Paulo: DIEESE, 2001.

JURUÁ, C.V. Perdas e danos: a lei das Parcerias Público-Privadas. Desemprego zero. Disponível em: <http://www.desempregozero.org.br/artigos/ perdas_e_danos.pdf >. Acesso em: 11 nov. 2005.

SGUISSARDI, V.; SILVA JR., J.R. A nova lei de educação superior:

Educ. Soc., Campinas, vol. 27, n. 96 - Especial, p. 1021-1056, out. 2006 
fortalecimento do setor público e regulação do privado/mercantil, ou continuidade da privatização e mercantilização do público? Revista Brasileira de Educação, Rio de Janeiro, n. 29, maio/ago. 2005c.

SGUISSARDI, V. Fundaçôes privadas na universidade pública - a quem interessam? Avaliação, Campinas, v. 7, n. 4, p. 43-72, dez. 2002b.

SGUISSARDI, V. Privatização da educação superior no Brasil 19952001. Revista de la Educación Superior, México, v. 31 (3), n. 123, p. 23-46, jul./set. 2002a.

SGUISSARDI, V. A universidade neoprofissional, heterônoma e competitiva. In: MANCEBO, D.; FÁvero, M.L.A. Universidade - políticas, avaliação e trabalho docente. S. Paulo: Cortez, 2004. p. 33-53.

SGUISSARDI, V. La universidad brasileña en tiempos de Lula. Revista de la Educación Superior, México, v. 33 (2), n. 134, p. 149-153, abr./jun. 2005a.

SGUISSARDI, V. Universidade pública estatal: entre o público e o privado/mercantil. Educação \& Sociedade, Campinas, v. 26, n. 90, p. 191-222, jan./abr. 2005b.

SMITH, A. A riqueza das naçôes. Lisboa: Fundação Calouste Gulbenkian, 1983. v. II.

VALENTE, I.; ROMANO, R. PNE: Plano Nacional de Educação ou carta de intenções. Educação \& Sociedade, Campinas, v. 23, n. 80, p. $97-$ 108, set. 2002.

WORLD BANK. Financing education in developing countries - an exploration of policy options. Washington, DC: The World Bank, 1986.

WORLD BANK. Higher education: the lessons of experience. Washington, DC: The World Bank Group, 1994. (Series Development in Practice).

WORLD BANK. The financing and management of higher education - a status report on worldwide reforms. Elaborado por D. Bruce Johnstone, com colaboração de Alka Arora e William Experton. Washington, DC: The World Bank, 1998.

WORLD BANK; TASK FORCE ON HIGHER EDUCATION AND SOCIETY. Higher education in developing countries: peril and promise. Washington, DC: The World Bank, 2000. Disponível em: <http://www.tfhe.net>. Acesso em: 20 jul. 2004. 